\title{
Workplace Bullying and Employee Performance Among Bank Personnel in Pakistan
}

\author{
Hafsa Hussain* and Qais Aslam**
}

\begin{abstract}
This study investigates the prevalence of workplace bullying for a sample of bank employees in Lahore. It also examines whether workplace bullying (measured as work-related bullying and person-related bullying) affects employees' performance in this context. On analyzing the data in terms of frequency and correlation, we find evidence to support the prevalence of bullying in these organizations, but none to suggest any association between workplace bullying and work performance.
\end{abstract}

Keywords: work-related bullying, person-related bullying, work performance.

JEL classification: J16, J27, M14.

\section{Introduction}

Workplace bullying has become a general concern for many organizations. It refers to the repeated mistreatment of an employee by his or her colleagues or employers (Kohut, 2007) and can include being ridiculed, humiliated, threatened, or harassed to the point that it affects one's performance at work. This has potential costs both to the employee and the organization itself, making it important to investigate the reasons, forms, and impact of workplace bullying on work performance.

Many studies distinguish between person-related and workrelated bullying. Work-related bullying can include, among other things, assigning unfair workloads or deadlines to an employee. Person-related bullying often includes unpleasant behavior such as insolence, teasing, spreading rumors, and playing practical jokes against someone (Bano \& Malik, 2013).

*Graduate student of commerce, University of Central Punjab, Lahore.

** Professor of economics, University of Central Punjab, Lahore. 
In this context, many organizations recognize the need to change the culture of the workplace and have developed clear policies to protect their employees from bullying (Bashir \& Hanif, 2011). A number of studies have also looked at the prevalence of this problem in Pakistan (see Anjum, Yasmeen, \&Yasmeen, 2011; Bano \& Malik, 2013; Bashir \& Hanif, 2011; Imran, Jawaid, Haider, \& Masood, 2010; Tahir \& Konstantinos, 2011). While the Protection against Harassment of Women at the Workplace Act 2010 was designed to counter instances of bullying against women, the success of its implementation remains uncertain.

The objectives of this study are to (i) identify the prevalence of bullying in banks in Pakistan, and (ii) establish the association between workplace bullying (both work-related and person-related) and employee performance. In this way, we hope to contribute to the literature on banking management and bank policies. We look at a sample of employees at two banks in Lahore: Allied Bank and Askari Bank.

\section{Literature Review}

Although the problem of bullying has always existed, it was not studied empirically until the 1970s, with researchers initially focusing on schools, workplaces, paramilitary organizations, and prisons(Tahir \& Konstantinos, 2011).Workplace bullying involves the use of authority to undermine or intimidate another person, often leaving the victim feeling powerless, under stress, incompetent, or ashamed (Yahaya et al., 2012; Imran et al., 2010).Moreover, this form of psychological abuse is carried out persistently over time and has a negative impact on the target's performance and wellbeing (Georgakopoulos, Wilkin, \&Kent, 2011).

Tariq and Ali (2012) define workplace bullying as persistent verbal and nonverbal aggression, which can include personal attacks, social ostracism, and hostile interaction. Lutgen-Sandvik, Namie, and Namie (2009) point out that workplace bullying usually involves a power disparity between both parties, with the targeted party often unable to stop or prevent the abuse. Turney (2003) identifies workplace bullying as a health and safety issue that is related to but separate from other forms of bullying.

Work-related bullying can include assigning unachievable targets, impossible deadlines, unmanageable workloads, or meaningless tasks to an employee. It can also include giving an employee deliberately unclear instructions or threatening his or her security. Workplace bullying 
ultimately has a negative impact on company performance and profitability (Yahaya et al., 2012; Bashir \& Hanif, 2011; Bano \& Malik, 2013). Person-related bullying, which tends to have a negative effect on workers' mental health (Yahaya et al., 2012),can include social exclusion, spreading rumors, ignoring someone's opinions, teasing, and making inappropriate sexual advances (Bashir \& Hanif, 2011;Bano \& Malik, 2013).

Work performance is a fundamental element of any organization (Khan et al., 2012) and entails successfully accomplishing an assigned task, subject to the normal constraints of reasonable utilization of the resources available (Dar, Akmal, Naseem, \& Khan, 2011).In this context, the consequences of workplace bullying (low motivation, absenteeism, high turnover, and low job satisfaction) are liable to affect work performance (Anjum et al., 2011).

Georgakopoulos et al. (2011) use qualitative data collected from a series of focus groups (comprising 112 undergraduate students, 72 Master's students, and 40 doctoral students) to conduct interpretive structural modeling. They find that certain organizational cultures can exacerbate workplace bullying when employers do not understand the problem or dismiss it as a form of tough management.

Yahaya et al. (2012) apply t-test and multiple regression techniques to a sample of 217 employees and find that person-related bullying is strongly correlated with work performance; this relationship varies, however, for local and foreign employees. Dar et al.(2011) collect data from a sample of 143 employees, using a structured questionnaire. They apply the chi-square and t-tests and find a negative relationship between job-related stress and work performance.

Bashir and Hanif (2011) use purposive convenient sampling to collect data for a sample of 280 telecommunication personnel in Pakistan. The data was drawn from a negative-acts questionnaire and analyzed through a pilot and a main study. The authors show that respondents had experienced workplace bullying at different points in their professional lives, where the incidence of work-related bullying was higher than that of person-related bullying. There were no significant gender differences. Anjum et al. (2011)gather qualitative data from 50 employees of different organizations in Bahawalpur and find that frequent bullying has severe health- and job-related consequences for people who are unable to prevent it. 


\section{Research Model and Hypotheses}

Based on the literature review above, Figure 1 show show the dependent variable, employee work performance, relates to the independent variable, workplace bullying.

The study's hypotheses are listed below:

$\mathrm{H}_{1}$ : workplace bullying is prevalent in the organization.

$\mathrm{H}_{0}$ : workplace bullying is not prevalent in the organization.

$\mathrm{H}_{1}$ : there is an association between workplace bullying and work performance in the organization.

$\mathrm{H}_{0}$ : there is no association between workplace bullying and work performance in the organization.

$\mathrm{H}_{2}$ : there is an association between work-related bullying and work performance in the organization.

$\mathrm{H}_{0}$ : there is no association between work-related bullying and work performance in the organization.

$\mathrm{H}_{3}$ : there is an association between person-related bullying and work performance in the organization.

$\mathrm{H}_{0}$ : there is no association between person-related bullying and work performance in the organization.

Figure 1: Research model

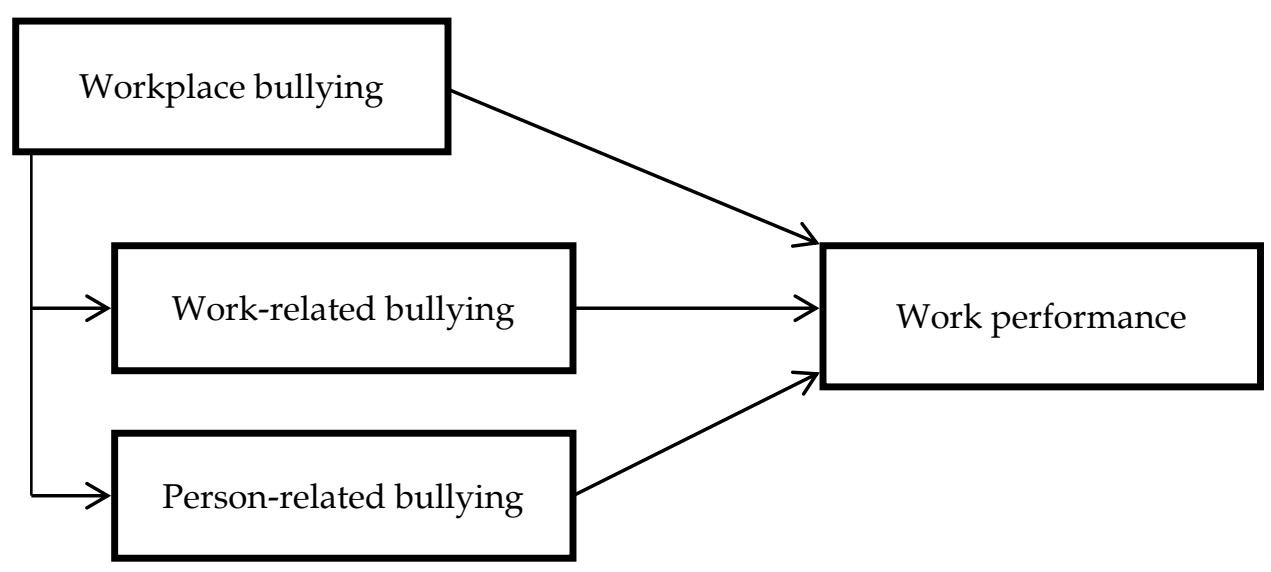




\section{Methodology}

In establishing the relationship between various dimensions of workplace bullying and employees' work performance, we identify the first as the independent variable and the second as the dependent variable. There are no control variables. The data collection method allows us to construct this as a cross-sectional study, with data available for the two variables at a single point in time.

Our sample was drawn from two banks in Lahore: Askari Bank and Allied Bank. We assume that the results obtained from the analysis can be generalized across all banks in the city. The data was collected using convenience nonprobability sampling and yielded a sample size of 117. A self-administered survey comprising 16 questions relating to the two dimensions of workplace bullying and their impact on work performance was conducted in both banks. Work performance was evaluated on the basis of task completion. The questions on work-related and person-related bullying were taken from Yahaya et al. (2012); those on work performance were structured by the study's authors.

The data collected was entered into Excel and then transferred to SPSS in order to run frequency, percentage, and correlation analyses to determine the prevalence of bullying in the sample and the association between workplace bullying and work performance.

\section{Results and Interpretation}

Table 1 indicates the results of the frequency analysis of workrelated bullying (see also Figures A1 to A7 in the Appendix). The sample comprised 117 responses with a mean of 3.0991 and a standard deviation of 0.65725. Overall, respondents agreed that the given dimensions of work-related bullying existed in their workplace. 
Table 1: Frequency analysis of work-related bullying

\begin{tabular}{lrrrrrr}
\hline Aspect of work-related bullying & & \multicolumn{1}{c}{$\mathbf{1}$} & $\mathbf{2}$ & \multicolumn{1}{c}{$\mathbf{3}$} & $\mathbf{4}$ & \multicolumn{1}{c}{$\mathbf{5}$} \\
\hline Someone withholds information, which affects & $\mathrm{F}$ & 12.0 & 13.0 & 30.0 & 55.0 & 7.0 \\
your work performance. & $\%$ & 10.3 & 11.1 & 25.6 & 47.0 & 6.0 \\
Your opinions and views are ignored. & $\mathrm{F}$ & 10.0 & 47.0 & 20.0 & 29.0 & 11.0 \\
& $\%$ & 8.5 & 40.2 & 17.1 & 24.8 & 9.4 \\
You are assigned tasks with unreasonable or & $\mathrm{F}$ & 7.0 & 30.0 & 31.0 & 36.0 & 13.0 \\
impossible targets or deadlines. & $\%$ & 6.0 & 25.6 & 26.5 & 30.8 & 11.1 \\
Your work is subject to excessive monitoring. & $\mathrm{F}$ & 6.0 & 33.0 & 31.0 & 27.0 & 20.0 \\
& $\%$ & 5.1 & 28.2 & 26.5 & 23.1 & 17.1 \\
& $\mathrm{~F}$ & 11.0 & 30.0 & 31.0 & 32.0 & 13.0 \\
You are pressured not to claim something to & $\%$ & 9.4 & 25.6 & 26.5 & 27.4 & 11.2 \\
which you are entitled (e.g., sick leave, travel & & & & & & \\
expenses). & $\mathrm{F}$ & 7.0 & 36.0 & 34.0 & 33.0 & 7.0 \\
You are assigned an unmanageable workload. & $\%$ & 6.0 & 30.8 & 29.1 & 28.2 & 6.0 \\
& $\mathrm{~F}$ & 9.0 & 18.0 & 40.0 & 38.0 & 12.0 \\
People you don't get along with carry out & $\%$ & 7.7 & 15.4 & 34.2 & 32.5 & 10.3 \\
practical jokes at work. & & & & & & \\
\hline
\end{tabular}

Notes: 1 = strongly disagree, $2=$ disagree, $3=$ neutral, $4=$ agree, $5=$ strongly agree.

Mean $=3.0991, \mathrm{SD}=0.65725, \mathrm{n}=117$.

Source: Authors' calculations.

The table shows that more than half (47 and 6 percent) the respondents felt that withholding information affected their work performance. Over a third(25 and 9 percent) felt their opinions and views were ignored. About 43 percent indicated that colleagues with whom they did not get along had carried out practical jokes at work. About 42 percent felt they had been given tasks with unreasonable or impossible targets or deadlines. Just over 40 percent agreed that their work was subject to excessive monitoring. Almost 39 percent felt they had been pressured not to claim something to which they were entitled, such as sick leave or travel expenses. Finally, about 34 percent agreed they had been exposed to an unmanageable workload.

Table 2 gives the results of the frequency analysis of personrelated bullying (see also Figures A8 to A14 in the Appendix). The sample mean is 3.4316 with a standard deviation of 0.81024 . Overall, respondents agreed that the given dimensions of person-related bullying existed in their workplace. 
Table 2: Frequency analysis of person-related bullying

\begin{tabular}{lrrrrrr}
\hline Aspect of person-related bullying & & $\mathbf{1}$ & $\mathbf{2}$ & $\mathbf{3}$ & $\mathbf{4}$ & $\mathbf{5}$ \\
\hline You are humiliated or ridiculed in connection & $\mathrm{F}$ & 9.0 & 22.0 & 23.0 & 38.0 & 25.0 \\
with your work. & $\%$ & 7.7 & 18.8 & 19.7 & 32.5 & 21.4 \\
You are ordered to carry out tasks below your & $\mathrm{F}$ & 4.0 & 9.0 & 21.0 & 53.0 & 30.0 \\
level of competence. & $\%$ & 3.4 & 7.7 & 17.9 & 45.3 & 25.6 \\
You have had key areas of responsibility & $\mathrm{F}$ & 5.0 & 24.0 & 19.0 & 42.0 & 27.0 \\
removed from your charge or replaced with & $\%$ & 4.3 & 20.5 & 16.2 & 35.9 & 23.1 \\
more trivial or unpleasant tasks. & & & & & & \\
People spread gossip or rumors about you. & $\mathrm{F}$ & 9.0 & 26.0 & 15.0 & 40.0 & 27.0 \\
& $\%$ & 7.7 & 22.2 & 12.8 & 34.2 & 23.1 \\
& $\mathrm{~F}$ & 4.0 & 24.0 & 38.0 & 31.0 & 20.0 \\
You are deliberately ignored or excluded. & $\%$ & 3.4 & 20.5 & 32.5 & 26.5 & 17.1 \\
& $\mathrm{~F}$ & 17.0 & 21.0 & 16.0 & 31.0 & 32.0 \\
People make offensive remarks about your & $\%$ & 14.5 & 17.9 & 13.7 & 26.5 & 27.4 \\
personality (habits and background), your & & & & & & \\
attitudes, or your private life. & $\mathrm{F}$ & 12.0 & 30.0 & 28.0 & 23.0 & 24.0 \\
You have been shouted at or been the target of & $\%$ & 10.3 & 25.6 & 23.9 & 19.7 & 20.5 \\
\hline
\end{tabular}

Notes: 1 = strongly disagree, $2=$ disagree, $3=$ neutral, $4=$ agree, $5=$ strongly agree.

Mean $=3.4316, \mathrm{SD}=0.81024, \mathrm{n}=117$.

Source: Authors' calculations.

More than half the respondents reported having been humiliated or ridiculed in connection with their work, with 32.5 percent indicating they agreed and 21.4 percent indicating they strongly agreed with this dimension. Almost 71 percent said they had been ordered to carry out tasks below their level of competence, while 59 percent reported having had key areas of responsibility removed from their charge or replaced with more trivial or unpleasant tasks. More than half the sample (34.2 and 23.1 percent) said they had been the target of gossip and rumors at work. Almost 44 percent said they had been deliberately ignored or excluded at work, while more than half (26.5 and 27.4 percent) said that colleagues had made offensive remarks about their habits, attitudes, or background. Finally, about 40 percent said they had been shouted at or been the target of spontaneous.

Table 3 gives the results of the frequency analysis of work performance (see also Figures A15 to A16 in the Appendix). The sample mean is 3.6282 with a standard deviation of 1.13933 . Almost 60 percent of the sample said they completed their assigned tasks within the given time, while over 61 percent reported carrying out their assignments according to the instructions they had been given. 
Table 3: Frequency analysis of work performance

\begin{tabular}{lrrrrrr}
\hline Aspect of work performance & & $\mathbf{1}$ & $\mathbf{2}$ & $\mathbf{3}$ & $\mathbf{4}$ & $\mathbf{5}$ \\
\hline You complete your assigned tasks in the given & $\mathrm{F}$ & 7.0 & 17.0 & 23.0 & 31.0 & 39.0 \\
time. & $\%$ & 6.0 & 14.5 & 19.7 & 26.5 & 33.3 \\
You carry out your assignments in the manner & $\mathrm{F}$ & 13.0 & 14.0 & 18.0 & 35.0 & 37.0 \\
instructed. & $\%$ & 11.1 & 12.0 & 15.4 & 29.9 & 31.6 \\
\hline
\end{tabular}

Notes: 1 = strongly disagree, $2=$ disagree, $3=$ neutral, $4=$ agree, $5=$ strongly agree.

Mean $=3.6282, \mathrm{SD}=1.13933, \mathrm{n}=117$.

Source: Authors' calculations.

A comparison of the means of work-related and person-related bullying (3.0991 and 3.4316, respectively) indicates that the latter dominates workplace bullying.Table4shows that the significance values of work-related and person-related bullying are greater than 0.01 . This implies that there is no significant association between work performance and either dimension of workplace bullying.

Table 4: Correlation analysis

\begin{tabular}{|c|c|c|c|c|}
\hline Variable & & $\begin{array}{c}\text { Work-related } \\
\text { bullying }\end{array}$ & $\begin{array}{c}\text { Person-related } \\
\text { bullying }\end{array}$ & $\begin{array}{c}\text { Work } \\
\text { performance }\end{array}$ \\
\hline \multirow{3}{*}{$\begin{array}{l}\text { Work-related } \\
\text { bullying }\end{array}$} & Pearson correlation & 1 & 0.113 & 0.095 \\
\hline & Sig. (2-tailed) & & 0.224 & 0.311 \\
\hline & $\mathrm{N}$ & 117 & 117 & 117 \\
\hline \multirow{3}{*}{$\begin{array}{l}\text { Person-related } \\
\text { bullying }\end{array}$} & Pearson correlation & 0.113 & 1 & 0.119 \\
\hline & Sig. (2-tailed) & 0.224 & & 0.200 \\
\hline & $\mathrm{N}$ & 117 & 117 & 117 \\
\hline \multirow{3}{*}{$\begin{array}{l}\text { Work } \\
\text { performance }\end{array}$} & Pearson correlation & 0.095 & 0.119 & 1 \\
\hline & Sig. (2-tailed) & 0.311 & 0.200 & \\
\hline & $\mathrm{N}$ & 117 & 117 & 117 \\
\hline
\end{tabular}

Note: ${ }^{* *}=$ correlation is significant at 0.01 level (two-tailed).

Source: Authors' calculations.

\section{Conclusion}

This study has attempted to analyze the prevalence of workplace bullying in banks in Pakistan and to identify any association between workplace bullying and work performance. Our results show that, although workplace bullying is prevalent in the sample, there is no significant association between workplace bullying and work performance. This could be for the following reasons: 
Given the low availability of good jobs in Pakistan, people are less likely to risk losing such jobs, even if it means putting up with abusive behavior at work.

People (and especially women) may not feel empowered enough to report instances of bullying by senior or powerful colleagues.

Respondents may not have answered all the survey questions accurately on account of a lack of trust.

In light of these results, we present the following recommendations:

Management should develop and implement policies that allow peopleand especially women-to report instances where they feel their work performance is being affected by workplace bullying.

Employees should be able to work in a friendly, secure environment in which they can easily share work-related issues with the management without fear of losing their jobs.

Seminars could be conducted regularly to help employees analyze and cope with such problems.

Laws that penalize workplace bullying must be introduced and implemented by the government. 


\section{References}

Anjum, A., Yasmeen, K., \&Yasmeen, K. (2011). Bullying at work: A comprehensive definition and consequences based on an empirical study. International Journal of Human Resource Studies, 1(1), 80-88.

Bano, S., \& Malik, S. (2013).Impact of workplace bullying on organizational outcome. Pakistan Journal of Commerce and Social Sciences, 7(3), 618-627.

Bashir, A., \& Hanif, R. (2011). Prevalence and forms of workplace bullying among telecommunication personnel in Pakistan. Interdisciplinary Journal of Contemporary Research in Business, 3(5), 634-647.

Dar, L., Akmal, A., Naseem, M. A., \& Khan, K. (2011). Impact of stress on employees' job performance in business sector of Pakistan. Global Journal of Management and Business Research, 11(6). Retrieved from http://journalofbusiness.org/index.php/GJMBR/article/view/5 $10 / 453$

Georgakopoulos, A., Wilkin, L., \&Kent, B. (2011). Workplace bullying: A complex problem in contemporary organizations. International Journal of Business and Social Science, 2(3), 1-20.

Imran, N., Jawaid, M., Haider, I. I., \&Masood, Z. (2010). Bullying of junior doctors in Pakistan: A cross-sectional survey. Singapore Medical Journal, 51(7), 592-595.

Khan, S. H., Azhar, Z., Parveen, S., Naeem, F., \& Sohail, M. M. (2012). Exploring the impact of infrastructure, pay incentives, and workplace environment on employees' performance (a case study of Sargodha University). Asian Journal of Empirical Research, 2(4), 118-140.

Kohut, M. R. (2007).The complete guide to understanding, controlling, and stopping bullies and bullying at work. Ocala, FL: Atlantic Publishing.

Lutgen-Sandvik, P., Namie, G., \& Namie, R. (2009). Workplace bullying: Causes, consequences, and corrections. In P. Lutgen-Sandvik \& B. D. Sypher (Eds.), Destructive organizational communication (pp. 4188). New York, NY: Routledge. 
Tahir, M. A., \&Konstantinos, B. (2011). Bullying among prison inmates in Pakistan: An exploration of the problem. Bi-Annual Research Journal "Balochistan Review", 24(1), 1-16.

Tariq, Q., \& Ali, S. M. (2012). Role of popularity in being bullied at the workplace. Pakistan Business Review, 13(4), 367-378.

Turney, L. (2003). Mental health and workplace bullying: The role of power, professions and "on the job" training. Australian e-Journal for the Advancement of Mental Health, 2(2), 99-107.

Yahaya, A., Tan, C. I., Gooh, M. L., Yahaya, N., Boon, Y., ... Taat, S. (2012). The impact of workplace bullying on work performance. Archives Des Sciences, 65(4), 18-28. 


\section{Appendix}

\section{Questionnaire}

Rate the following aspects of workplace bullying and work performance where 1 = strongly disagree, 2 = disagree, $3=$ neutral, $4=$ agree, 5 = strongly agree.

\begin{tabular}{|c|c|c|c|c|c|c|}
\hline & Aspect & & & ale & & \\
\hline 1 & $\begin{array}{l}\text { Someone withholds information, which affects your work } \\
\text { performance. }\end{array}$ & 1 & 2 & & & 5 \\
\hline 2 & You are repeatedly reminded of your mistakes. & 1 & & 3 & & 5 \\
\hline 3 & People you don't get along with carry out practical jokes at work. & 1 & 2 & 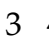 & & 5 \\
\hline 4 & $\begin{array}{l}\text { You are assigned tasks with unreasonable or impossible targets or } \\
\text { deadlines. }\end{array}$ & 1 & 2 & 3 & & 5 \\
\hline 5 & People spread gossip or rumors about you. & 1 & & 3 & & 5 \\
\hline 6 & People make allegations against you. & 1 & & 3 & & 5 \\
\hline 7 & You are assigned an unmanageable workload. & 1 & 2 & 3 & & 5 \\
\hline 8 & You are humiliated or ridiculed in connection with your work. & 1 & & 3 & & 5 \\
\hline 9 & You are ordered to carry out tasks below your level of competence. & 1 & & 3 & & 5 \\
\hline 10 & $\begin{array}{l}\text { You have had key areas of responsibility removed from your } \\
\text { charge or replaced with more trivial or unpleasant tasks. }\end{array}$ & 1 & 2 & 3 & & 5 \\
\hline 11 & Your work is subject to excessive monitoring. & 1 & & 3 & & . \\
\hline 12 & You are deliberately ignored or excluded. & 1 & 2 & 3 & & 5 \\
\hline 13 & $\begin{array}{l}\text { People make offensive remarks about your personality (habits } \\
\text { and background), your attitudes, or your private life. }\end{array}$ & 1 & & & & 5 \\
\hline 14 & You have been shouted at or been the target of spontaneous anger. & 1 & 2 & 3 & & 5 \\
\hline 15 & Your opinions and views are ignored. & 1 & & & & 5 \\
\hline 16 & $\begin{array}{l}\text { You are subjected to intimidating behavior (finger pointed at you, } \\
\text { personal space invaded, shoved, your path blocked, hints that } \\
\text { you should quit your job). }\end{array}$ & 1 & & & & 5 \\
\hline 17 & Your work or effort is persistently criticized. & 1 & & 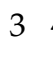 & & J \\
\hline 18 & You carry out your assignments in the manner instructed. & 1 & & & & 5 \\
\hline 19 & $\begin{array}{l}\text { You are subjected to threats of violence or physical abuse or to } \\
\text { actual abuse. }\end{array}$ & 1 & & & & 5 \\
\hline 20 & You are the object of excessive teasing and sarcasm. & 1 & & 3 & & 5 \\
\hline 21 & $\begin{array}{l}\text { You are pressured not to claim something to which you are } \\
\text { entitled (e.g., sick leave, travel expenses). }\end{array}$ & 1 & & & & 5 \\
\hline 22 & You complete your assigned tasks in the given time. & 1 & & 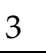 & & \\
\hline
\end{tabular}

Gender: (i) male or (ii) female Qualifications: (i) undergraduate, (ii) postgraduate, or (iii) doctoral Designation: (i) low-level, (ii) mid-level, or (iii) top-level 
Years employed in present organization: (i) less than 5 years, (ii) less than 10 years, or (iii) 10 years or more

Years in current position: (i) less than 5 years, (ii) less than 10 years, or (iii) 10 years or more

\section{Frequency analysis}

Figure 2: Someone withholds information, which affects your work performance

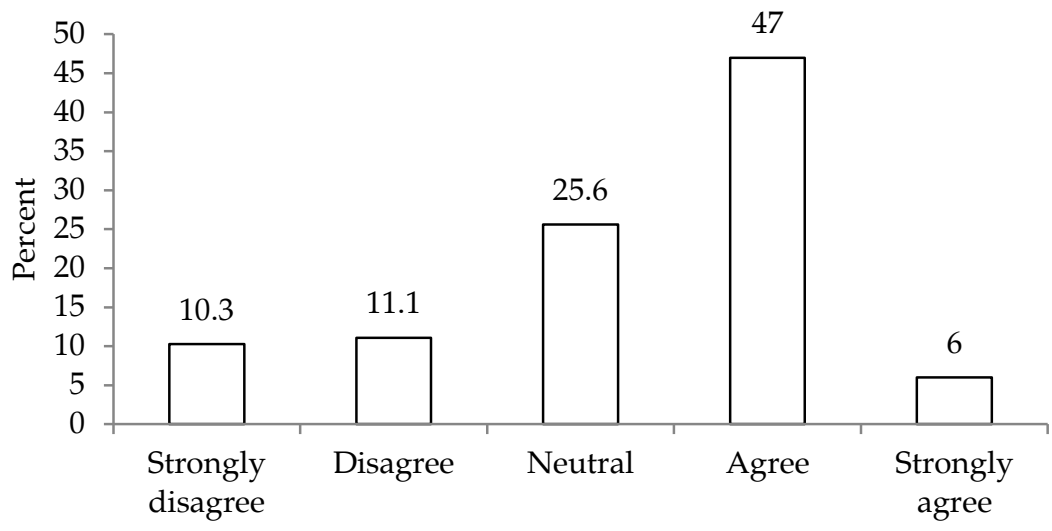

$\square$ Someone withholds information, which affects your work performance

Figure 3: Your opinions and views are ignored

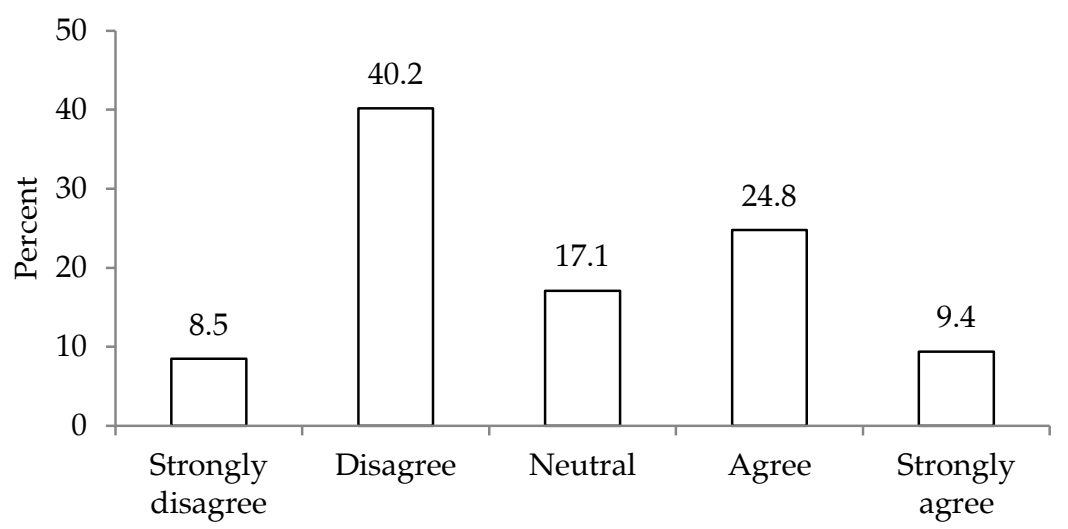

$\square$ Strongly disagree $\square$ Disagree $\square$ Neutral $\square$ Agree $\square$ Strongly agree 
Figure 4: You are assigned tasks with unreasonable or impossible targets or deadlines

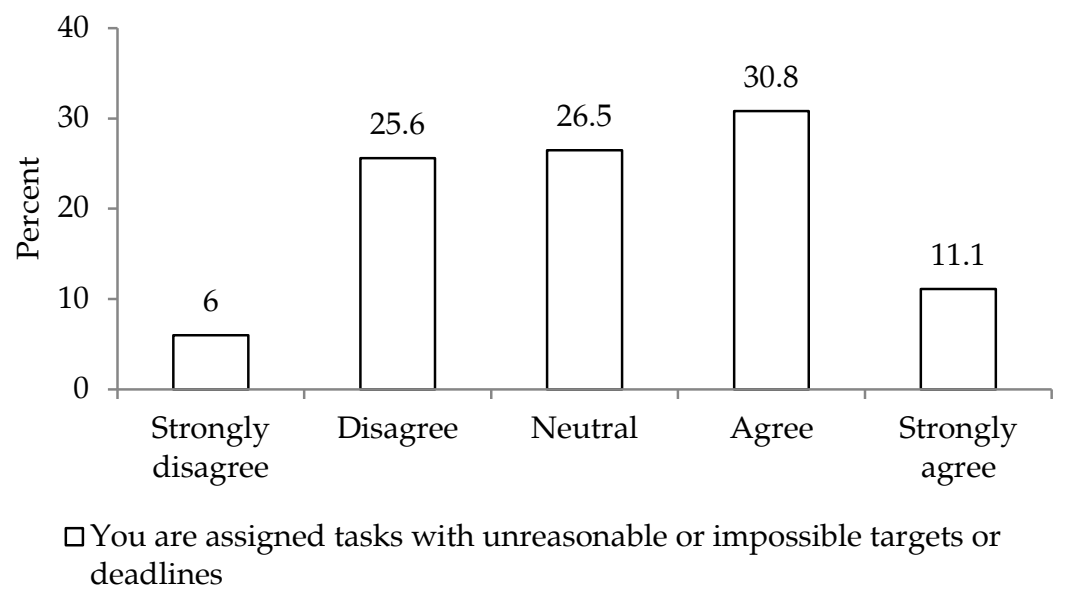

Figure 5: Your work is subject to excessive monitoring

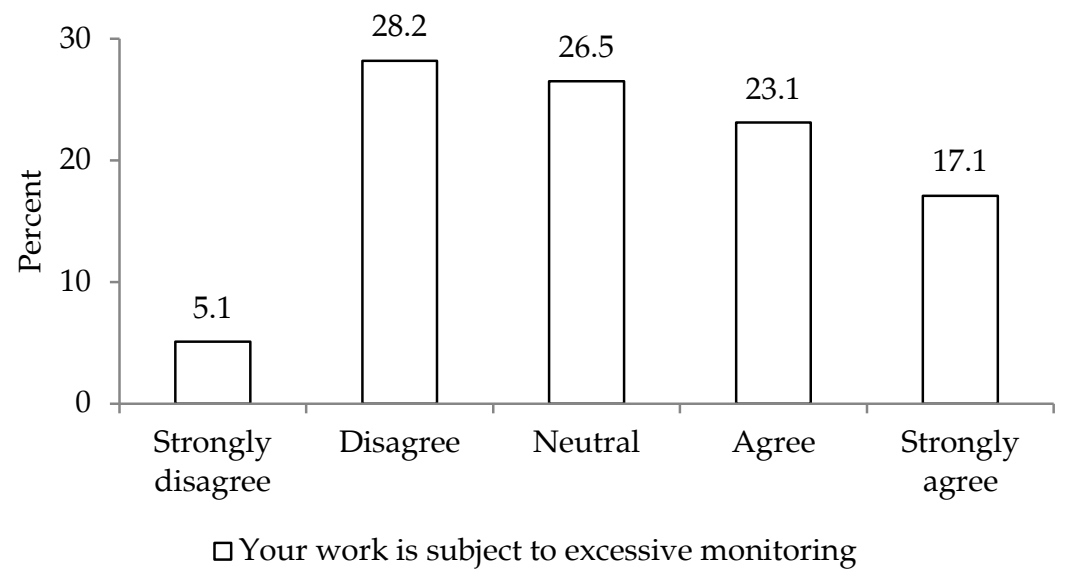


Figure 6: You are pressured not to claim something to which you are entitled

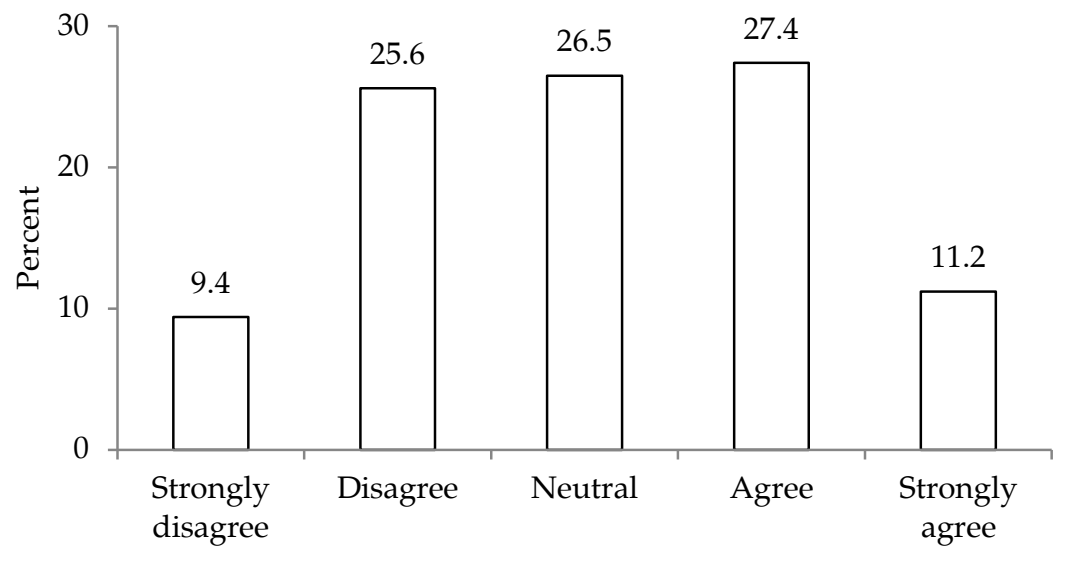

$\square$ You are pressured not to claim something to which you are entitled (e.g., sick leave, travel expenses)

Figure 7: You are assigned an unmanageable workload

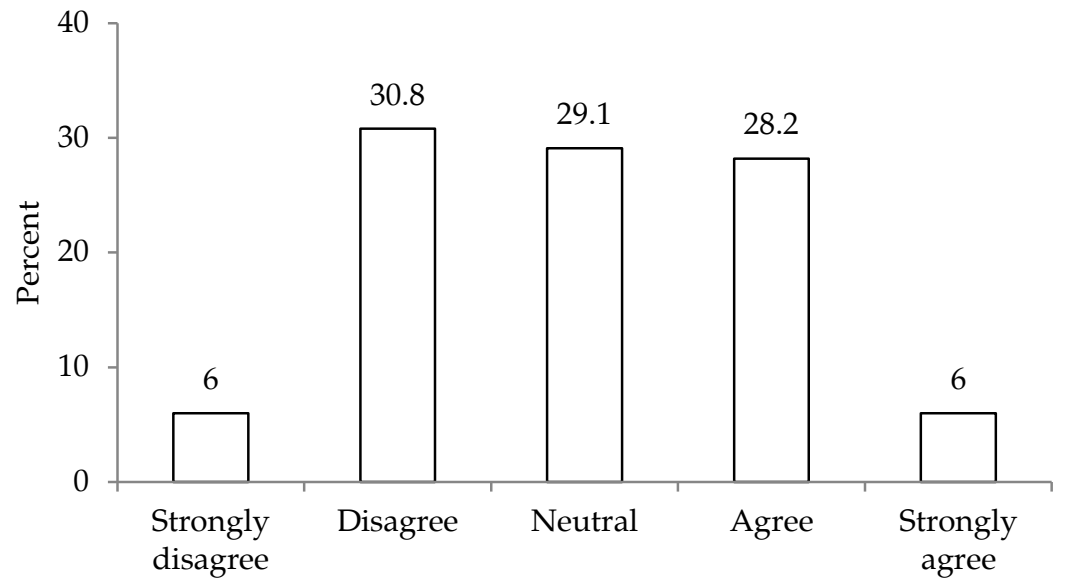

口You are assigned an unmanageable workload 
Figure 8: People you don't get along with carry out practical jokes at work

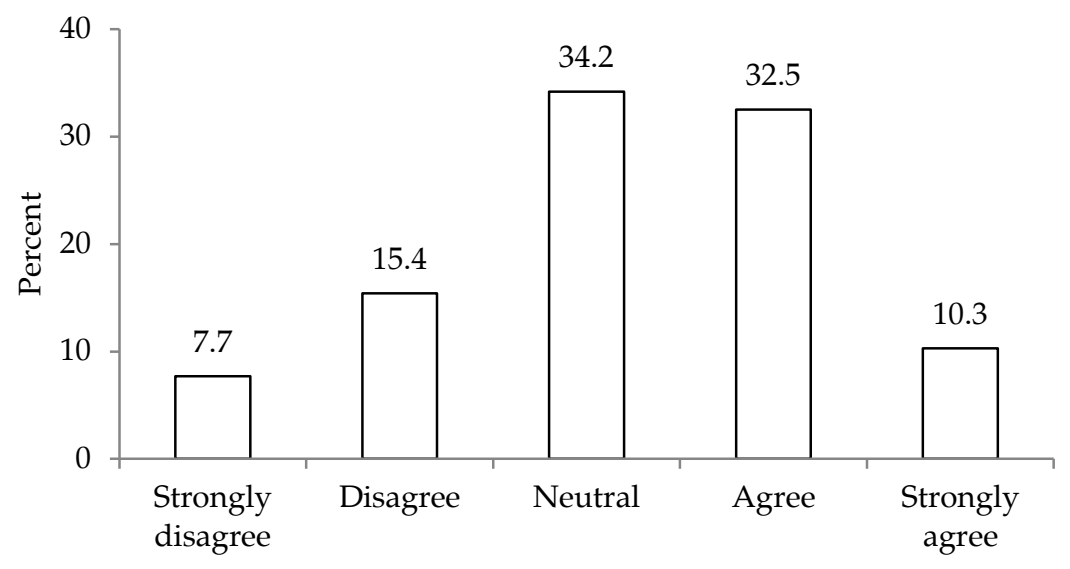

$\square$ People you don't get along with carry out practical jokes at work

Figure A8: You are humiliated or ridiculed in connection with your work

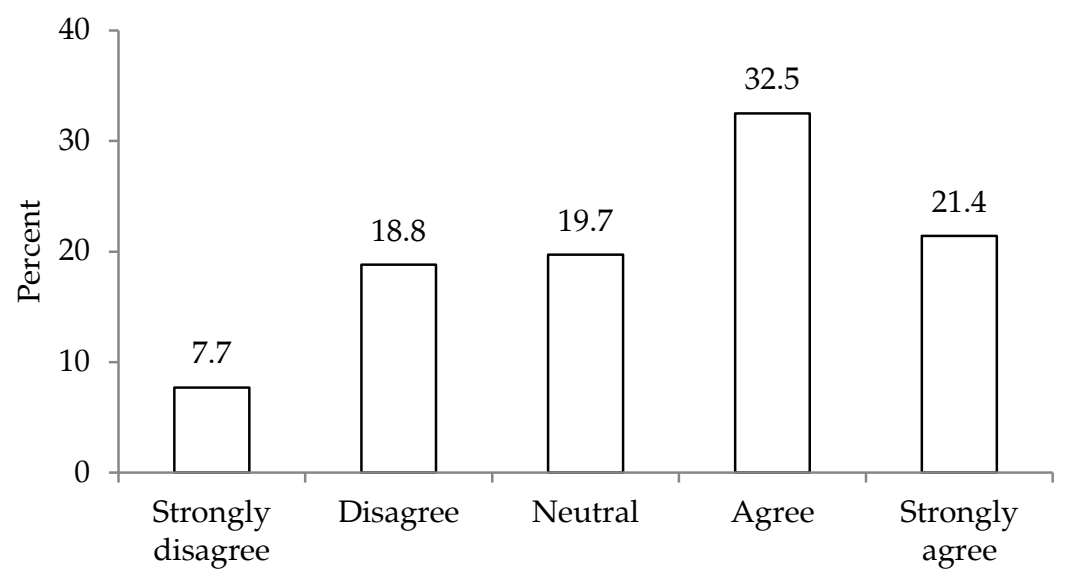

$\square$ You are humiliated or ridiculed in connection with your work 
Figure A9: You are ordered to carry out tasks below your level of competence

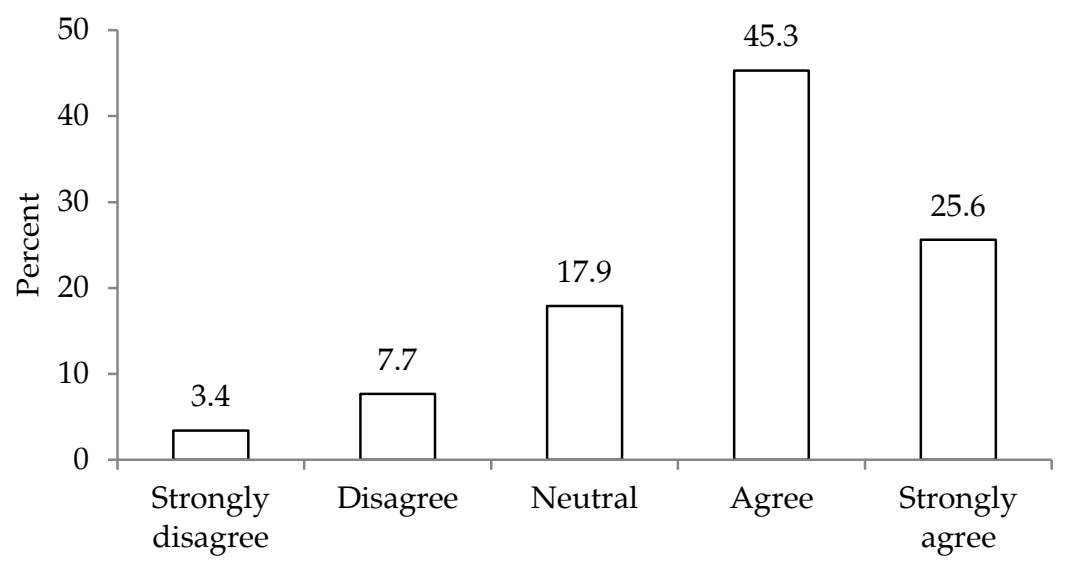

口You are ordered to carry out tasks below your level of competence

Figure A10: You have had key areas of responsibility removed from your charge or replaced with more trivial or unpleasant tasks

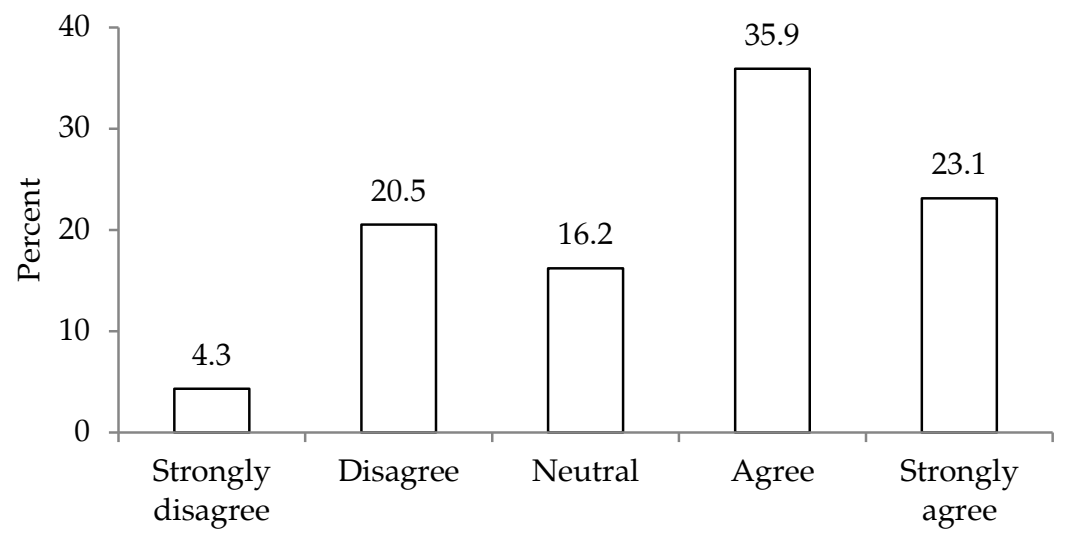

$\square$ You have had key areas of responsibility removed from your charge or replaced with more trivial or unpleasant tasks 
Figure A11: People spread gossip or rumors about you

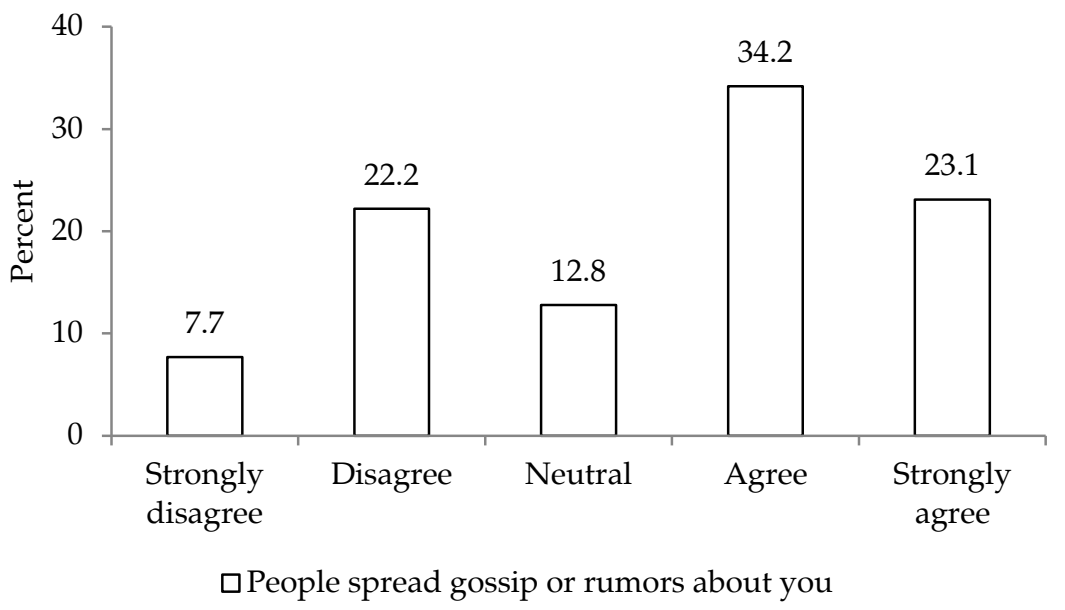

Figure A12: You are deliberately ignored or excluded

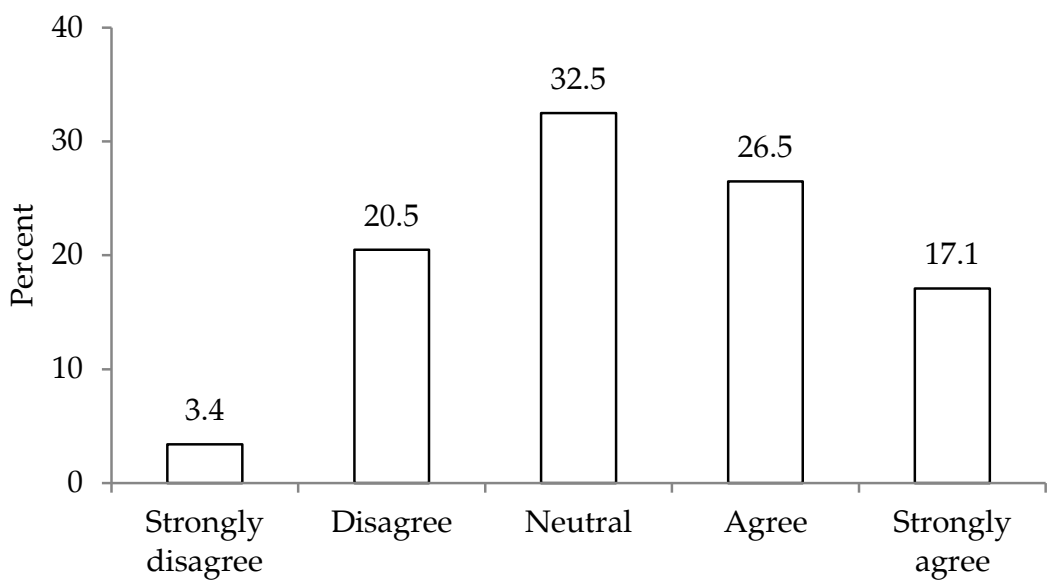

口You are deliberately ignored or excluded 
Figure A13: People make offensive remarks about your personality, your attitudes, or your private life

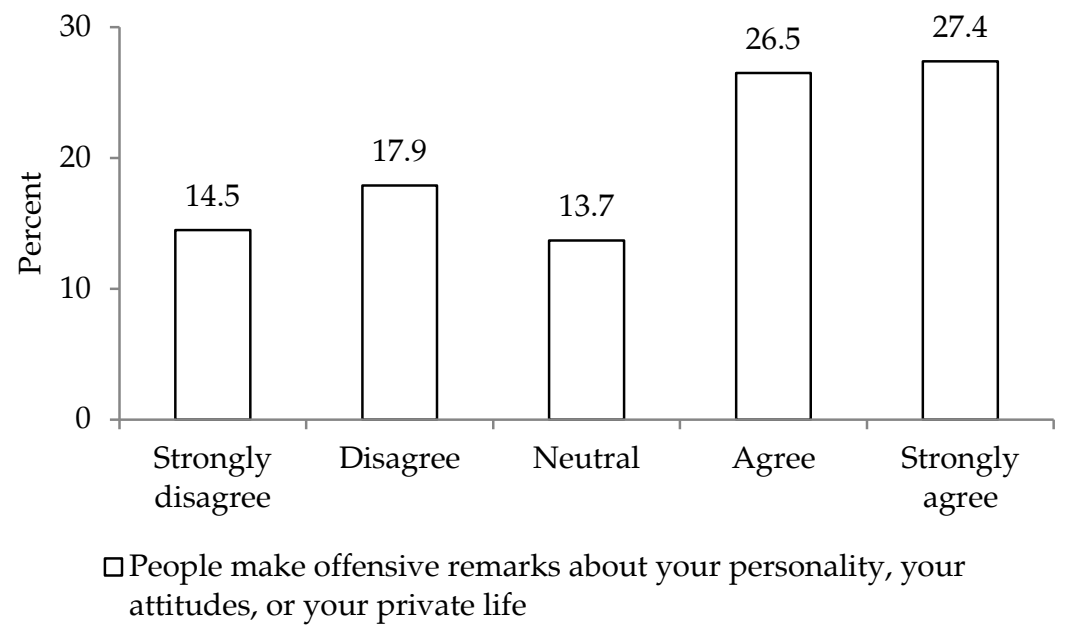

Figure A14: You have been shouted at or been the target of spontaneous anger

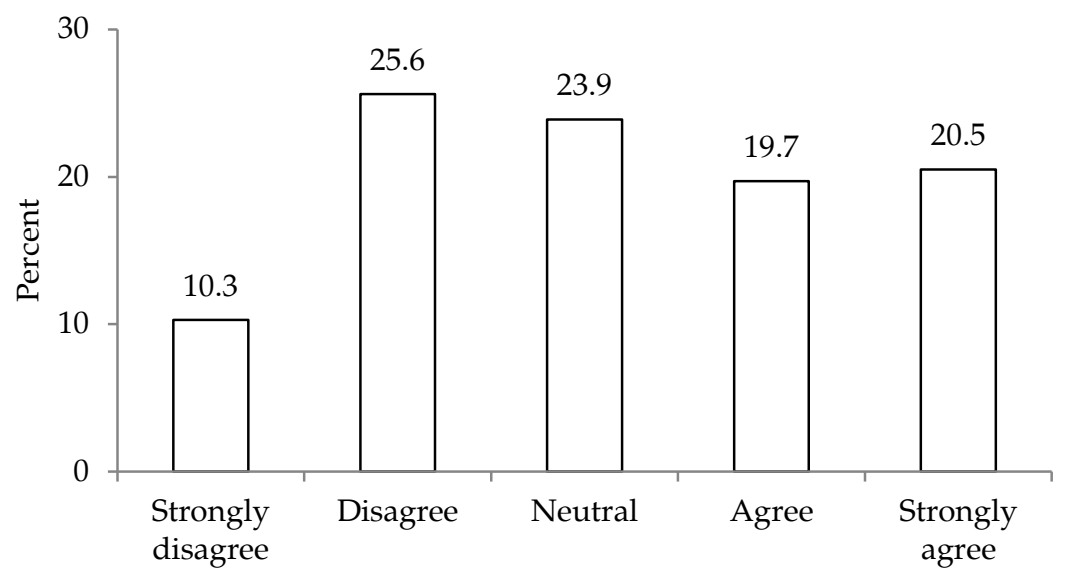

$\square$ You have been shouted at or been the target of spontaneous anger 
Figure A9:You complete your assigned tasks within the given time

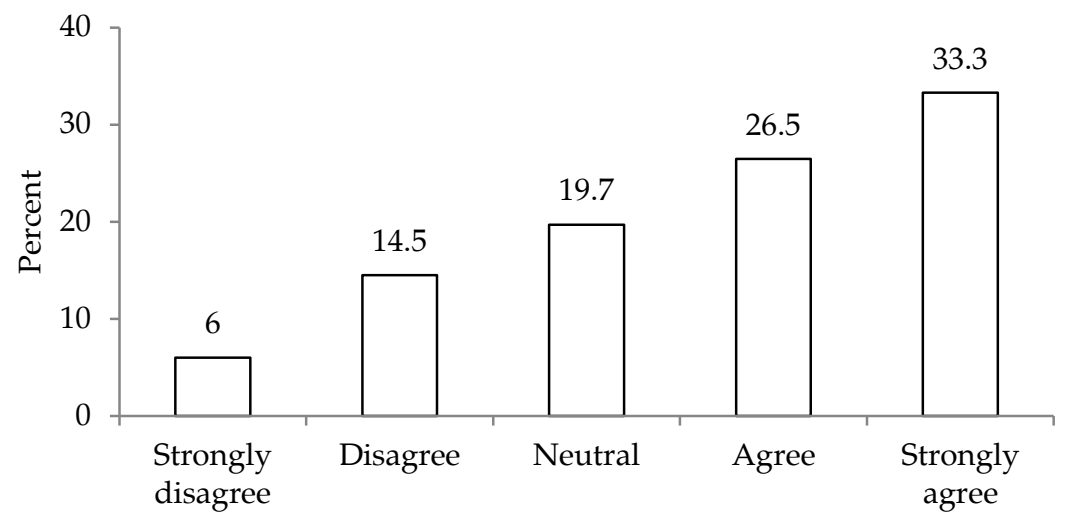

$\square$ You complete your assigned tasks within the given time

Figure 10: You carry out your assignments in the manner instructed

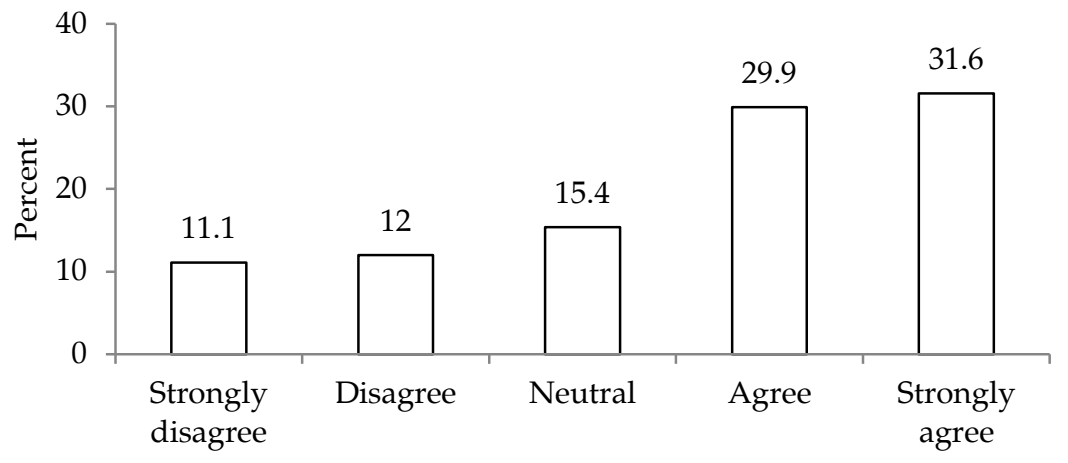

$\square$ You carry out your assignments in the manner instructed 